\title{
Acceptable erosion rates for mine waste landform rehabilitation modelling in the Pilbara, Western Australia
}

\author{
EJ Howard Landloch Pty Ltd, Australia \\ RJ Loch Landloch Pty Ltd, Australia
}

\begin{abstract}
A major concern for rehabilitation and closure of waste landforms on mine sites is their long-term erosion stability. In Western Australia, regulators are requesting landforms remain 'stable' for hundreds of years or the 'long-term'. Therefore, assessing a landform's potential long-term erosion stability requires the use of erosion and/or landform evolution models and defensible erosion thresholds below which rehabilitation landform designs are considered acceptably erosion resistant or 'stable'.

The Pilbara Rehabilitation Group, through four member companies-BHP, Fortescue Metals Group, Rio Tinto, and Roy Hill-initiated a project aimed at defining acceptable rates of erosion for rehabilitation landform design for the Pilbara region of Western Australia. As part of the project, a review of information relating to erosion rates on natural and man-made landforms was conducted. This review showed that a wide range of approaches have been used to define acceptable erosion rates, including linking them to rates of soil formation; maintenance of soil quality, which may include considerations of plant/crop productivity, effective soil depth, and soil organic matter and nutrient stores; rates of natural erosion in adjoining areas; potential for gully formation; and water quality impacts. Based on this review, a guideline was developed to define acceptable erosion rates for use in the design of stable mine waste landforms in the Pilbara region. The guideline uses a risk-based approach, with erosion thresholds being linked to the waste material's physical properties and the adverse environmental impacts that may result from landform failure.
\end{abstract}

Keywords: landform design, erosion, acceptable rates, Pilbara

\section{Introduction}

A major concern for rehabilitation and closure of mining waste landforms is their long-term erosion stability. In Western Australia, regulators are requesting landforms remain 'stable' for hundreds of years or the 'longterm'. With these time frames in mind (hundreds of years), assessing a constructed landform's potential 'long-term' erosion stability requires the use of erosion and/or landform evolution models. Use of these models in the mining context began in the mid-1990s and they continue to be used today (e.g. Evans \& Loch 1996; Hancock et al. 2000; Howard \& Lowe 2014; Braun et al. 2018).

Important to the modelling process is the establishment of erosion threshold values below which landform designs are considered acceptably stable. Without this, it is not possible to assess the performance of different waste landform rehabilitation designs in terms of absolute erosion (Willgoose \& Hancock 2011). Typically, rehabilitation landform designs are adjusted until a design is identified that meets the erosion threshold value adopted (often erosion is one of several factors that have a bearing on the final rehabilitation design).

There is currently no published source that seeks to establish an acceptable erosion rate for mine waste landforms, with values often used being based on unpublished research data, field-based observations, and published values from soil erosion literature. The Pilbara Rehabilitation Group (PRG) established a project to undertake a review of available information relating to acceptable erosion rates, and to develop a guideline that can be used to establish which erosion threshold values should be adopted for design of rehabilitated landforms for their sites, based on a range of factors. 


\section{Design of waste landforms and acceptable soil losses}

\subsection{Regulatory expectations}

The need to manage long-term erosion from rehabilitated mine site landforms is captured in guidance documents produced by both the Australian Federal and Western Australian State Governments. The Leading Practice Sustainable Development Program for the Mining Industry's Handbook on Mine Closure (Commonwealth of Australia 2016a) states that:

The slope of the landform surface and the nature of the soil and mine waste materials directly affect critical long-term objectives, such as resistance to erosion, the integrity of encapsulation of hostile wastes, the capacity to accept and store rainfall, and the capacity to support plant growth (p. 50)

The effective functioning of landforms and meeting completion criteria critically require geotechnical stability; resistance to erosion; appropriate management and disposal of excess water during storms; storing potential infiltration while minimising impacts from deep drainage; and ensuring the availability of soil moisture for vegetation (p. 51)

The Western Australia Department of Mines, Industry Regulation and Safety's (then Department of Mines \& Petroleum) Environmental Notes on Mining that relate to waste rock dumps (Department of Mines \& Petroleum 2009) state that dump batter profiles are to be designed to

"Ensure that the final structure is safe, stable and not prone to significant erosion. Factors that should be considered in the design are material types, proposed vegetation cover, natural topography and climate" (p. 1)

Based on these excerpts, there is limited clarity on what might be considered 'stable'. An expectation of zero erosion is unreasonable and is clearly not considered in the guideline excerpts presented earlier. In practice, there is a continuum of erosion outcomes, ranging from landforms with little measurable erosion, landforms with isolated instances of erosion, through to landforms that have extensive and highly active erosion. A method for identifying an acceptable rate of erosion would be extremely valuable. For design purposes, a spatially-averaged erosion rate is a practical threshold to be applied and is consistent with historical soil erosion science methods. There is also temporal variation in rainfall and erosion hazard to be considered. For waste landforms, most designs are based on periods of rainfall record in the order of 100 years, and aim to deliver acceptable rates of erosion over that period, accepting that, as is normal, there will be years within that period when erosion will be higher or lower than the average. For some situations, designs may consider longer time periods in excess of 1,000 years, if, for example, dealing with radioactive wastes (Willgoose \& Riley 1998) or other materials of concern. Equally, for some situations, consideration of specific design storms may be relevant, though only for landforms where there is potential for an event to exceed the capacity of the designed runoff control structures (e.g. berms, bunding, drains) and cause irreversible damage. However, for many waste landform designs, consideration of design storms is not as important as assessing long-term erosion rates. (Dump top bunds are structures that do require appropriate engineering design).

\subsection{The need for erosion modelling thresholds}

There is little long-term benefit in designing and rehabilitating a waste landform in such a way that it is highly likely to be subject to excessive rates of erosion. Equally, it is impractical to set acceptable erosion rate values so low as to be unachievable. Consequently, clarity on what constitutes an acceptable or threshold rate of erosion to underpin landform design is important to all groups involved in mine site rehabilitation and closure including design consultants, mining companies, and regulators. Without the establishment of an acceptable erosion rate, it is very difficult to classify different designs as being successful or unsuccessful. 


\subsection{Designing landforms}

Since the late 1990s, mine sites in Australia have increasingly relied on some form of erosion prediction to design waste landform batter profiles that, once rehabilitated, will erode at a rate less than some designated threshold rate. This approach has been publicly presented and discussed in public forums and within peerreviewed conference and journal papers over many years (Loch 1997; Loch \& Willgoose 2000a, 2000b; Hancock et al. 2003; Hancock 2004; Loch \& Lowe 2008; Loch 2010; Howard et al. 2011; Braun et al. 2018). Model simulations allow a wide range of landform design options to be tested rapidly, enabling selection of an option that-for the local materials and climate-will erode at a rate less than the designated threshold value. The use of models to design landforms has achieved a number of documented successes (Howard et al. 2010; Squires et al. 2012; Howard \& Lowe 2014) and avoided some more serious failures.

Studies have confirmed that the model/s used are accurate under field conditions (Figure 1) provided the input parameters used are accurate. The authors commonly use the Water Erosion Prediction Project (WEPP) model for batter slope design (Flanagan \& Livingston 1995). Erosion data shown in Figure 1 were sourced from 27 locations on 12 waste landforms on mine sites in Western Australia. The observed erosion data were collected using cross-slope transects and erosion plots that captured runoff and erosion from an entire batter slope section. Batter shapes include uniform, convex, and concave profiles. Gradients are consistent with the steep slopes commonly used for mining landforms. Surfaces assessed include loamy soils, clay soils, and rocky sandy loam soils. The ages of the batters range from three to eight years. Slope conditions range from minimally eroded to heavily eroded. Frequent and infrequent rainfall events are included.

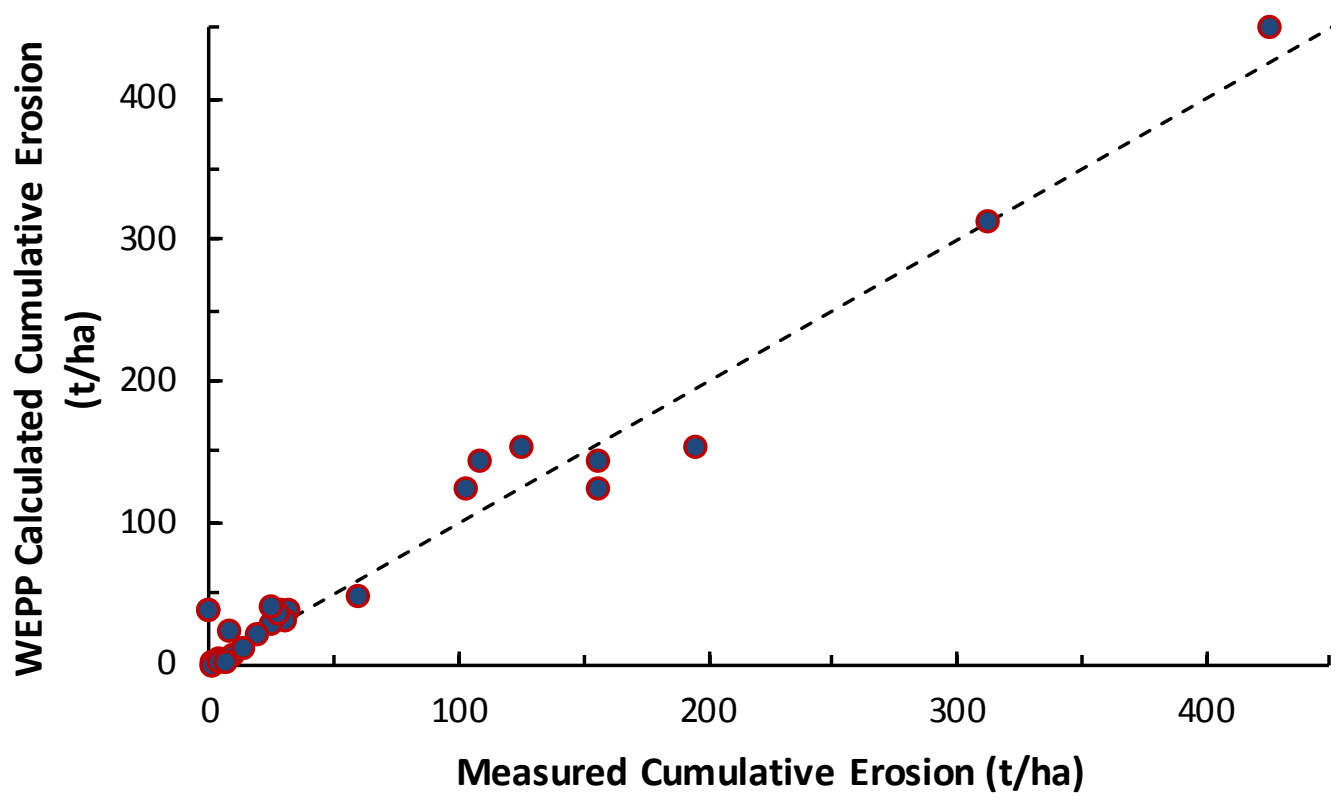

Figure 1 Model predicted cumulative erosion and observed cumulative erosion rates for 27 batter slope locations from Western Australian mine sites

The measured cumulative erosion rates show excellent agreement with rates predicted by WEPP. The accuracy of the predictions shown in Figure 1 also indicates that the methods used to derive the essential model parameters are producing well calibrated model results. This gives confidence that models can be used to usefully consider erosion of mine waste landforms.

\subsection{Dealing with risk and uncertainty}

Notwithstanding this, a degree of long-term uncertainty is inevitable and a strategy is required to manage it. To this end, it is important to consider the following: 
- The potential to expose encapsulated hostile wastes, creating a high potential risk to the environment.

- Materials for which erosion rates are likely to increase or decrease over time.

- Designs that increase or decrease the potential for long-term increases in erosion rates.

- Situations where increases in erosion rates may pose relatively high risks to the environment.

These factors can be used to set risk ratings for specific landforms, with those ratings then used to set different acceptable erosion rates based on risk.

\section{Acceptable erosion rates using different concepts}

A search of the available literature showed that a wide range of concepts have been used to define an acceptable rate of erosion. They include linking erosion rates to:

- Rates of soil renewal.

- Maintenance of soil quality, which may include considerations of:

- Plant/crop productivity.

- Effective soil depth.

- Soil organic matter and nutrient stores.

- Rates of natural erosion in adjoining areas.

- Gully development.

- Water quality and connectivity.

- Impacts on vegetation.

For some approaches, there is extensive published information. For others, data are limited and supplementary calculations and erosion simulations have been used to enable them to be more thoroughly considered. The following sections examine these approaches in greater detail and identify those approaches with greatest relevance to mine site rehabilitation in the Pilbara region.

\subsection{Erosion tolerance values - United States agricultural lands and rangelands}

\subsubsection{United States agricultural lands}

Initial attempts to define a 'tolerable' rate of erosion began in United States (US) agriculture and were closely linked to the development of methods to predict erosion rates (the birth of erosion modelling). Soil erosion prediction in the US developed through a number of equations, including those of Zingg (1940), Smith (1941), Browning et al. (1947), and Musgrave (1947), which gradually increased the range of factors considered. These developments culminated in the release of the Universal Soil Loss Equation (USLE) (Wischmeier \& Smith 1965). With the development of the USLE, US soil conservationists could, for the first time, identify sets of management practices that, if adopted, would ensure that an acceptable erosion rate would not be exceeded.

A definition of tolerable erosion was proposed by Browning et al. (1947) and a more thorough review of tolerable values was carried out by the Soil Science Society of America in 1979. In general, US soil conservationists have consistently based tolerable soil loss values largely on consideration of the maintenance of soil productivity, although acknowledging that other factors may be important in some situations. U.S. soil conservation agencies have typically used tolerable erosion values of $<11.2 \mathrm{t} / \mathrm{ha} / \mathrm{y}$ for deep fertile soils, and $<4.5 \mathrm{t} / \mathrm{ha} / \mathrm{y}$ for shallow agricultural soils. 


\subsubsection{United States rangelands}

When compared to agricultural soils, rangeland soils tend to be shallower, are often located in lower rainfall areas, and support comparatively lower levels of vegetation. Soil formation in rangeland soils tends to be less rapid. Rangeland soils also tend to not be actively managed through addition of fertilisers or the ploughing of plant materials back into the soil profile to assist nutrient cycling (Rollins 1981). For these reasons, lower acceptable erosion values have historically been adopted in US rangeland management. The value is consistent to those of the shallower agricultural soils. An acceptable rate of $<4.5 \mathrm{t} / \mathrm{ha} / \mathrm{y}$ is commonly used (McCormack et al. 1982; Wight \& Siddoway 1982; Rollins 1981).

\subsubsection{A note on time periods considered}

It is notable that US considerations of an acceptable rate of erosion clearly accepted an aim of maintaining soil productivity for a long period (e.g. 200 years) rather than in perpetuity. Similarly, Bui et al. (2010) used time intervals of 100,200 , and 500 years when developing critical erosion rate estimates in a soil erosion study covering the whole of Australia.

\subsection{Rates of soil renewal}

In assigning acceptable erosion rates that would maintain soil productivity, there is an assumption that any loss of soil and nutrients is being balanced by additions to the soil profile from weathering of parent material and accumulation from fluvial or aeolian deposition.

\subsubsection{Soil formation rate}

Estimates of soil formation rates vary depending on parent rock type (igneous, sedimentary), parent rock condition (fractured, unfractured, fresh, transitional, weathered), rainfall (being greater in wetter soil), and impacts of topography, temperature, and vegetation, with some evidence that even in arid zones, adapted vegetation may produce distinctive weathering patterns that favour certain ecosystems (Sawkins et al. 2011; Verboom et al. 2013).

Estimates of soil formation rates are generally low when considering undisturbed soils. Logan (1982) suggested that most rates of soil formation are in the order of $0.5 \mathrm{t} / \mathrm{ha} / \mathrm{y}$. Alexander (1988) estimated rates of soil formation by weathering in the range of 0.02-1.9 t/ha/y for catchments with noncarbonate lithologies. Heimsath et al. (1997) showed an inverse relationship between soil formation rates and soil depth in northern California, with rates ranging from $0.4 \mathrm{t} / \mathrm{ha} / \mathrm{y}$ for deeper soils to $0.9 \mathrm{t} / \mathrm{ha} / \mathrm{y}$ for shallower soil. More recently, Heimsath et al. (2009) suggested maximum weathering rates of about $0.26 \mathrm{t} / \mathrm{ha} / \mathrm{y}$ under $35-40 \mathrm{~cm}$ of soil for a Northern Territory site. Verheijen et al. (2009) suggest somewhat higher rates of soil formation by weathering for Europe of 0.3-1.2 t/ha/y. Stocking (1978) reports formation rates of 0.2-0.4 t/ha/y for small granite catchments with iron-rich soils in central Africa.

Edwards \& Zierholz (2007) note that average land denudation rates (at the continental scale) are in the order of $1 \mathrm{~mm}$ of soil per 100 years, and suggest that-assuming soil depths are typically remaining relatively constant-this implies an average rate of soil formation from unweathered bedrock in the order of $0.13 \mathrm{t} / \mathrm{ha} / \mathrm{y}$. For Australia, that average rate is likely to vary greatly across the country in response to large variations in rainfall, geology, vegetation, and temperature, and is not necessarily helpful as a consequence. They suggest that an upper limit for tolerable soil loss for long-term sustainability of dryland agriculture should be in the order of $1.0 \mathrm{t} / \mathrm{ha} / \mathrm{y}$. Similarly, Bui et al. (2010) suggest a tolerable soil loss rate of $0.2 \mathrm{t} / \mathrm{ha} / \mathrm{y}$ for much of Australia, increasing to $0.4 \mathrm{t} / \mathrm{ha} / \mathrm{y}$ for areas where dust deposition is important. The degree to which numbers based on continental scale data are skewed downwards by Australia's large areas of arid zone is not known.

However, for shallow artificial soils on mine sites, the rate of A-horizon renewal is likely to be more rapid than the rates of soil formation in natural catchments, reported by Logan (1982) and Edwards \& Zierholz (2007), due to several factors. Firstly, rocks and other materials in mine waste are typically fractured by 
blasting and excavation and subsequent handling and shaping and as such, they have a higher specific surface that leads to more rapid weathering and breakdown (Spain \& Hollingsworth 2016). Secondly, the upper layer of waste (directly underlying any soil applied or even at the surface in some situations) is the zone that would be most regularly subjected to wetting and drying, which would also increase its rate of weathering. Thirdly, the uppermost layer of the waste would also have greatest exposure to plant roots and some biotic processes that would accelerate weathering. Consistent with that, for soils formed on mine spoil, Bini \& Gaballo (2006) measured the thickness of the A-horizon and found that A-horizon thickness increased linearly with increasing soil age, at a rate of $1.3 \mathrm{t} / \mathrm{ha} / \mathrm{y}$, which is reasonably consistent with some of the higher rates estimated for soil weathering reported earlier in the paper.

\subsubsection{Accumulation of dust}

For Europe, Verheijen et al. (2009) report measurements of dust deposition ranging up to $0.4 \mathrm{t} / \mathrm{ha} / \mathrm{y}$ and noted that there are reports from some regions of up to $3.0 \mathrm{t} / \mathrm{ha} / \mathrm{y}$ deposition of dust, indicating that the impact of dust deposition (relative to rock weathering) could be significant in some areas. For the Pilbara, although there are no data on rates of dust deposition, it should be noted that the region lies in the northwest pathway of dust movement (Kiefert et al. 1996) and is therefore exposed to considerable dust moving from major source areas in central Australia. Rates of dust deposition in the Broken Hill area (in the southeast pathway of dust movement) have been reported to be as high as $1 \mathrm{t} / \mathrm{ha} / \mathrm{y}$. Consequently, dust accumulation rates in the Pilbara region may be as high as $1 \mathrm{t} / \mathrm{ha} / \mathrm{y}$, significantly adding to potential rates of soil renewal.

\subsubsection{Overview of soil renewal information}

It appears that under undisturbed conditions, rates of soil formation are likely to be in the range of 0.02 $1.9 \mathrm{t} / \mathrm{ha} / \mathrm{y}$. Given that rates of weathering of fractured rock in mine waste close to the soil surface are likely to be high compared to undisturbed soils and dust accumulation may be up to $1 \mathrm{t} / \mathrm{ha} / \mathrm{y}$, it appears that rates of soil renewal in the Pilbara may be in the order of 1.5 to as much as $4.0 \mathrm{t} / \mathrm{ha} / \mathrm{y}$ in situations of high soil renewal and dust accumulation rates.

\subsection{Maintenance of soil quality}

Larson \& Stewart (1990) suggest that soil quality can be considered to reflect soil attributes that are either irreplaceable or replaceable. Irreplaceable properties include water holding capacity and rooting depth. Replaceable properties include nutrients and organic matter.

For the Pilbara region, naturally-occurring soils vary with landscape position. However, stony soils, shallow loams, and shallow sands are common on hillslopes, with deeper sands present in alluvial and lower slope areas (van Vreeswyk et al. 2004; Tille 2006). Due to subdued plant growth in the Pilbara's arid climate, soil chemical fertility is generally regarded as being low. For example, Blandford (2010) noted for soils in the Hardey project area that "organic carbon is low, suggesting poor chemical fertility, poor moisture retention capability, and low levels of plant available nitrogen". Consequently, the irreplaceable properties (water holding capacity and root depth) are likely to be limited due to impacts of rock and coarse texture on water holding capacity, and limited soil depth available for root expansion. The replaceable (fertility) attributes are also likely to be low.

Soil profiles constructed during waste landform rehabilitation in the Pilbara show both similarities and differences to naturally-occurring soils in the area. Constructed mining soil profiles typically consist of either a shallow growth medium layer placed over a mine waste or simply a waste with no addition of soil. The waste is often not hostile to plant growth. Like natural soils, mine waste is often rocky and coarse textured (sandy). An important difference is that constructed profiles tend to be much deeper than naturally-occurring soils. Consequently, water holding capacity within the rooting zone is likely to be higher for the constructed profile compared to the shallower natural soils. This means that water holding capacity is less susceptible to reduction by erosion for a constructed profile than the natural soils. For the same reason, rooting depth is also likely less susceptible to reduction by erosion for a constructed profile. Depending on rehabilitation 
methods and fertiliser addition, chemical fertility of a constructed soil profile may be similar to that of natural soils (though organic carbon will, at least initially, be lower). Given that fertiliser additions (when applied) are generally small in concentration and mixed into the surface layers, the chemical fertility of a constructed soil profile in an arid environment is likely less sensitive to reduction by erosion than that of natural soils, which are likely to have a concentration of organic carbon rich soils close to the surface (Loch et al. 2008). Effectively, the lack of strong horizon development typical of constructed soil profiles is expected to render them less susceptible to the impacts of erosion than some, if not all, natural soils in the Pilbara region.

For these reasons, development of an acceptable erosion rate based on maintenance of soil quality seems inappropriate.

\subsection{Rates of erosion in the Pilbara and adjacent regions}

There are limited data for erosion rates in the Pilbara region. A study using ${ }^{137} \mathrm{Cs}$ to assess erosion (McFarlane et al. 2000) reported rates of $20.4 \mathrm{t} / \mathrm{ha} / \mathrm{y}$ and $27.6 \mathrm{t} / \mathrm{ha} / \mathrm{y}$ for two rangeland sites in the Pilbara close ( $30 \mathrm{~km})$ to the coast, and $3.4 \mathrm{t} / \mathrm{ha} / \mathrm{y}$ and $6.6 \mathrm{t} / \mathrm{ha} / \mathrm{y}$ for two inland sites in the Gascoyne ( $200 \mathrm{~km}$ from the coast). All four sites were located on lower gradient slopes subject to grazing, and not subject to significant rill erosion. It is likely that surface disturbance by grazing caused some increase in erosion rates relative to those of undisturbed sites. Two field-based rainfall simulation and overland flow studies on undisturbed rangeland plots near Tom Price (Gallagher 2008) and on the Juna Downs pastoral station yielded erodibility and infiltration parameters that allow for the prediction of long-term erosion. For batters $20 \mathrm{~m}$ high and gradients of $16^{\circ}$, long-term erosion rates from these undisturbed rangeland hillslopes ranged from $1-8 \mathrm{t} / \mathrm{ha} / \mathrm{y}$. A nationwide assessment of interrill (sheetwash) and rill erosion (Lu et al. 2003) reported erosion rates for the Pilbara region ranging from 1-5 to 10-50 t/ha/y, with the higher rates likely associated with steeper landforms in the east of the Pilbara. The paper used the Revised Universal Soil Loss Equation (RUSLE) (Renard et al. 1997) to estimate erosion rates and did not allow for the effect of rock on the steeper sites. Hence, the reported values are likely an overestimate for soils containing an appreciable coarse fraction on steeper gradient land.

Consequently, it appears likely that rates of erosion in the inland Pilbara region are in the order of 3-8 t/ha/y on grazed hill slopes and that rates of erosion from low-gradient valley floors and from rocky landforms are likely to be in the order of $1-8 \mathrm{t} / \mathrm{ha} / \mathrm{y}$. That range is similar to those originally considered for U.S. agriculture and rangeland soils.

\subsection{Rill and gully development}

As hillslope length/catchment area increases, erosion processes change. At small hillslope length/catchment area, erosion is dominated by raindrop impacts, either directly on the soil or on shallow overland flows. As catchment area and flow rates increase, erosion becomes dominated by detachment and transport by flow in either rills or gullies.

It is typical for steeply sloping mining landform batters to have sufficient slope length/catchment area to be prone to rill and gully erosion. Generally, there is a significant increase in erosion rates associated with rill development (Meyer et al. 1975; Loch \& Donnollan 1983; Govers \& Poesen 1988), and a further increase when the rills become gullies. Loch \& Donnollan (1983) found that clearly incised rills carried $\sim 5$ times the coarse sediment load of broad, flat flow lines that could be equated with interrill transport.

Klingebiel (1961) suggested that erosion rates $>11 \mathrm{t} / \mathrm{ha} / \mathrm{y}$ led to gullying. The authors have measured erosion on heavily gullied surfaces on three mining waste landforms in the Pilbara. Erosion rates associated with high rates of gully erosion were $>40 \mathrm{t} / \mathrm{ha} / \mathrm{y}$ (Figure 2). Nine large-scale erosion plots have been operational at an iron ore mine site in the Pilbara region of Western Australia since July 2012. Three heavily rilled and gullied plots had a measured average erosion rate of $28 \mathrm{t} / \mathrm{ha} / \mathrm{y}$. The remaining six plots are not heavily rilled or gullied and have a measured average erosion rate of $2 \mathrm{t} / \mathrm{ha} / \mathrm{y}$ (Figure 3). Erosion monitoring data collected at the Murrin Murrin Cobalt-Nickel mine site are reported in the Australian Leading Practice Sustainable Development Program for the Mining Industry handbook titled Evaluating Performance: Monitoring and 
Auditing (Commonwealth of Australia 2016b). Five measures of erosion on batter slope sections with limited rilling showed average annual erosion rates $<8 \mathrm{t} / \mathrm{ha} / \mathrm{y}$. Two measures of erosion on batter slope sections with rills and gullies had measured annual erosion rates of $>20 \mathrm{t} / \mathrm{ha} / \mathrm{y}$.

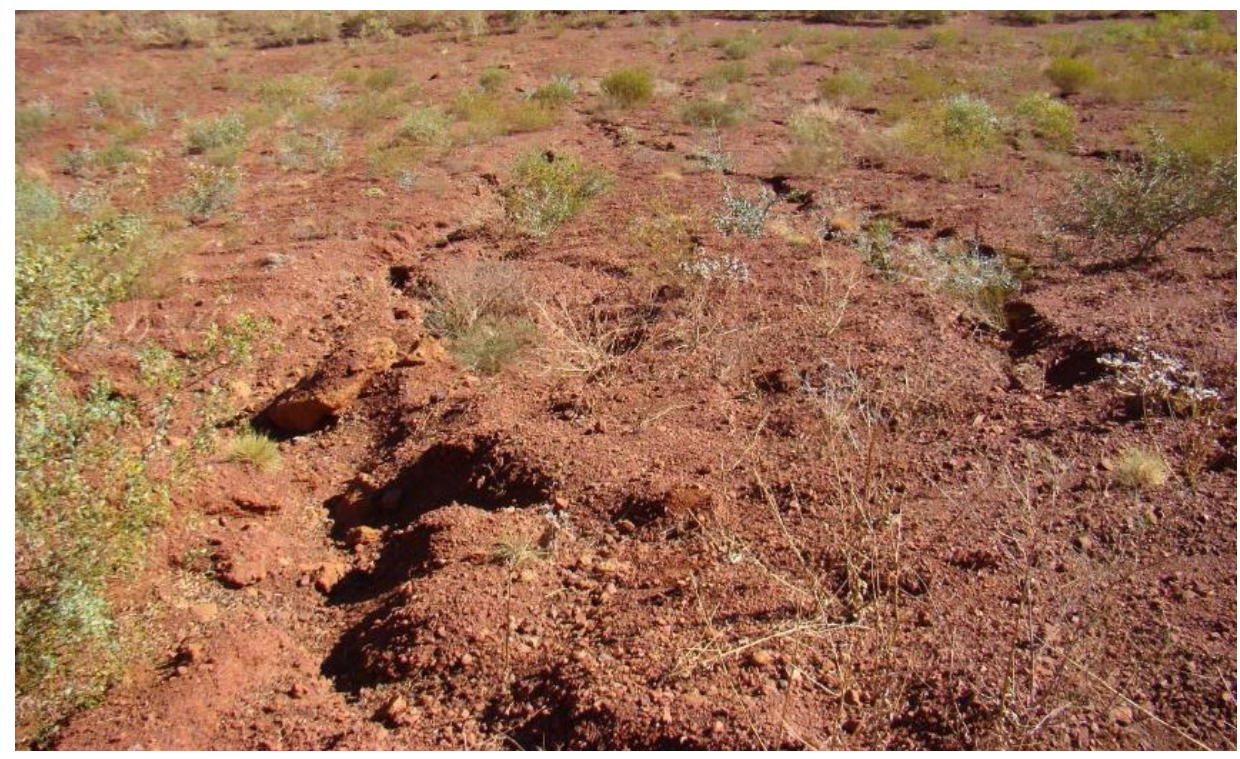

Figure 2 Erosion on a banded iron formation-dominated waste dump batter eroding at a rate of $40 \mathrm{t} / \mathrm{ha} / \mathrm{y}$. Gullies are a dominant erosion feature

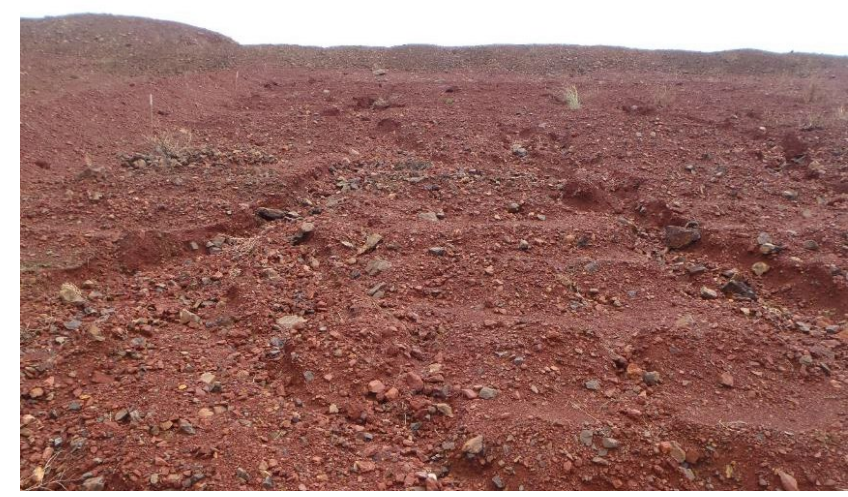

(a)

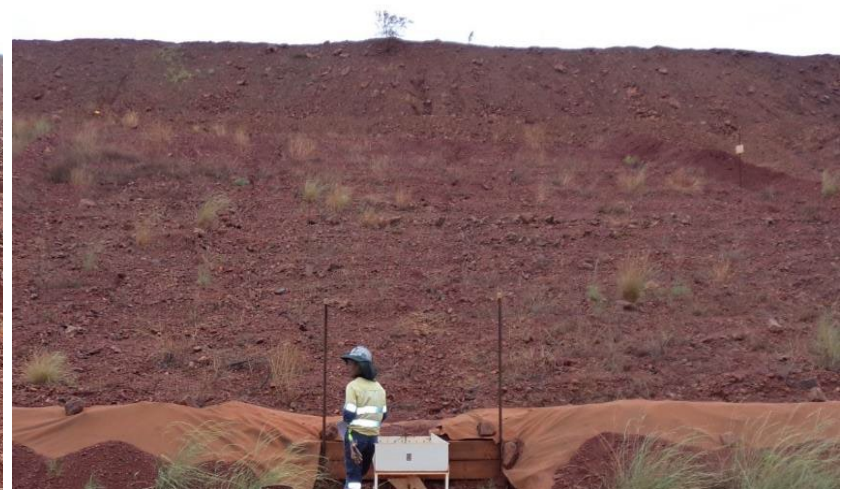

(b)

Figure 3 Erosion plots at a Pilbara mine site. Plots are sheeted with (a) detritals and eroding at an average rate of $28 \mathrm{t} / \mathrm{h} / \mathrm{y}$ and (b) a mixture of detritals and rocky hydrated zone waste, eroding at an average rate of $2 \mathrm{t} / \mathrm{ha} / \mathrm{y}$

In rangeland or mine site situations, the concentration of flow associated with rilling can entrench a pattern of increased scour by overland flows (Moliere et al. 2002) and can result in gradual formation of gullies over time. This can occur even when overall erosion rates are seemingly low. For example, even an erosion rate as low as $4 \mathrm{t} / \mathrm{ha} / \mathrm{y}$ measured over a reasonable width of batter could cause significant gully development over the long-term if landform conditions favour gully development. These conditions would include sharp inward curving land surface shapes or poor surface elevation control that cause convergence of runoff and increased erosion potential at discrete locations (Berghofer \& Howard 2016). Alternately, rates as high as $12 \mathrm{t} / \mathrm{ha} / \mathrm{y}$ would cause only limited gully development over the long-term if conditions for gully development were not favourable. For this reason, it appears appropriate to include a consideration of gully development potential in the framework by which acceptable erosion rates are determined. 


\subsection{Runoff water quality and connectivity}

For the Pilbara region, suspended sediment load data proved scarce. The draft Environmental Impact Statement for the Wheatstone Project (Chevron Australia Pty Ltd 2010) notes for rivers in northwest Western Australia that

"Suspended sediments have been measured directly on a few occasions, however the majority of suspended sediment concentrations have been indirectly measured as turbidity. Very little data currently exists for the north west of Western Australia for both suspended sediment concentrations and estimated sediment loading to marine environments."

That report also notes that

"Turbidity for the Ashburton River ranges from less than 10 NTU over a range of flows from $30 \mathrm{~m}^{3} / \mathrm{sec}$ to $250 \mathrm{~m}^{3} / \mathrm{sec}$, to 3,300 NTU at a flow rate of around $250 \mathrm{~m}^{3} / \mathrm{sec}$. The flow weighted turbidity for the Ashburton River is 1,705 NTU, which is higher than other Pilbara river sites, which range from 10-587 NTU."

Data for total suspended sediment from 2010 to 2016 were sourced for the Fortescue and Ashburton Rivers, and the Weeli Wolli, Marillana, and Kalgan Creeks. Median total suspended solids values for the Fortescue and Ashburton Rivers is $8.5 \mathrm{mg} / \mathrm{L}$, with the range being 1-960 mg/L. The median total suspended solids value for the Weeli Wolli, Marillana, and Kalgan Creeks is $4 \mathrm{mg} / \mathrm{L}$, with the range being $0.5-320 \mathrm{mg} / \mathrm{L}$. The data are consistent with observations that rivers in the Pilbara area can, in large runoff events and under natural, undisturbed conditions, carry high concentrations of both bed and suspended load. Unstable, rapidly eroding waste landforms could well produce high concentrations of both bed and suspended sediments, but the potential for such movements to have detrimental impacts on fluvial systems is difficult to assess because of the:

- Likely differences in sediment concentrations between source (waste landform) and receptor (creek or river at high flow).

- Potential for dilution of the input flow if the fluvial system's flow rate is much larger than the volume of runoff from the waste landform.

- Connectivity between source and receptor, which could vary with event size, and may, for example, affect bed and suspended sediment fractions differently.

In the absence of available data and the complexities outlined above, an alternative, simplified approach to considering potential risk of erosion to fluvial systems is to consider the:

- Sensitivity of the receiving environment to sediment deposition.

- Potential for sediment to deposit on the sensitive receptor.

- Degree and frequency of connectivity from the waste landform to the sensitive receptor.

Using this approach, identification of high value receiving environments is done during the approvals process, with acceptable erosion rates defined based on the risk identified as part of the approvals process.

\subsection{Impacts on vegetation}

Erosion affects vegetation by reducing soil productivity, exposing roots in areas of scour, burying vegetation in areas of deposition, and occasionally creating deposits of sediment that may increase vegetation growth. Within the Pilbara region, an assessment of the condition of undisturbed lands (van Vreeswyk et al. 2004) notes that

"Erosion problems have started and accelerated primarily as a consequence of loss of ground cover by overgrazing or other disturbance or where natural processes (such as overland sheet water flow) have been fragmented or disrupted." 
Effectively, erosion is regarded as a consequence of loss of ground cover, rather than being the cause. For rehabilitated mining areas, exposure of roots and death of plants in areas of incision undoubtedly occurs, but there were no available reports found of this process having significant impacts on rehabilitation success. There are anecdotal reports of increased vegetation diversity and growth in stabilising gully areas in response to increased water (captured by the gully) and possible benefits from deposited 'topsoil'. However, there are no data linking quantitative rates of erosion to specific degrees of vegetation damage that could assist in identifying rates of acceptable erosion in this instance.

\section{Selection of an acceptable erosion rate}

Conclusions reached as part of the review of acceptable erosion concepts for the Pilbara region are summarised as:

- Rates of soil renewal are likely to fall in the range of 1.5-4.0 t/ha/y.

- The productivity of constructed soil profiles in the Pilbara is likely to be less sensitive to erosion than is that of naturally-occurring soils.

- Natural rates of erosion occurring in the Pilbara region are likely to fall in the range $1-8 \mathrm{t} / \mathrm{ha} / \mathrm{y}$, with the highest rate being modelled rather than measured. Measured rates ranged from 3.4-6.6 t/ha/y.

- Erosion rates similar to those identified for soil renewal and natural erosion rates can lead to gully erosion if landform conditions favour gully development.

- Considerations of the potential impacts of offsite movements of sediment to fluvial systems are complex, and also limited by a lack of data. The lack of data makes establishing rates based on vegetation impact impossible at this stage.

Based on this information and given the likely relatively low susceptibility of constructed soil profiles to reduction in quality due to erosion, it is recommended that the maximum likely rate of soil renewal ( $4 \mathrm{t} / \mathrm{ha} / \mathrm{y})$ be considered when setting erosion thresholds. Further, given that estimates of natural erosion rates in the region have reported maximum values of $6 \mathrm{t} / \mathrm{ha} / \mathrm{y}$ (measured) and $8 \mathrm{t} / \mathrm{ha} / \mathrm{y}$ (modelled), it seems reasonable to suggest that a value of $6 \mathrm{t} / \mathrm{ha} / \mathrm{y}$ be adopted as a working acceptable erosion rate for use in landform designs. This rate refers to average erosion of the whole slope. Where erosion modelling for design purposes is able to consider variations in erosion rates at various points on a slope profile, an additional condition should be set that erosion rate at any point should not exceed the target threshold average rate by more than $100 \%$ due to the potential for initiation of active rill erosion (and eventual gully development) at those points, as illustrated in Figure 4.

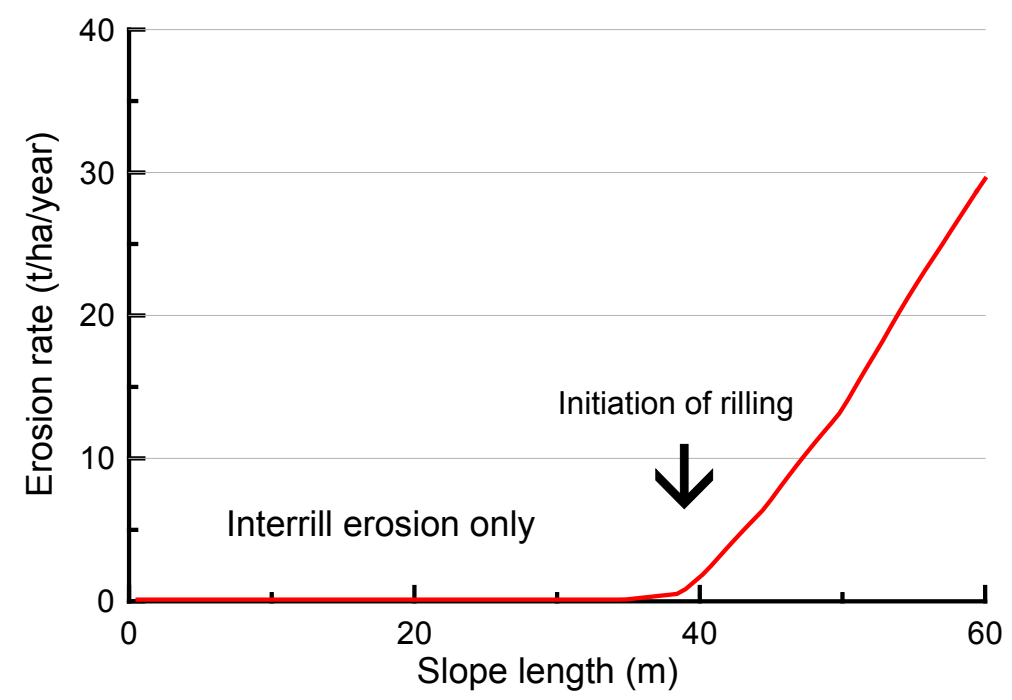

Figure 4 Example of model output for a linear batter of rocky waste, showing changes in predicted erosion rate and process with increasing slope length (distance from the crest of the batter) 


\section{$5 \quad$ Uncertainty and environmental consequences}

\subsection{Likelihood, consequence, and risk ratings}

For rehabilitated mine site landforms, considerations of their long-term performance (given the levels of certainty that can be achieved) include:

- Whether there is potential for erosion rates or hostility of eroded material to significantly increase if some encapsulated material is exposed;

- Potential for eroded sediment to impact on an aquatic ecosystem of significance or sensitivity; and

- Whether erosion rates are likely to increase or decrease over time, which includes potential for surfaces to armour and relative sensitivity to gully development.

Broadly, those considerations identify the degree to which the specific landform has the risk to perform poorly under some conditions, and in particular, whether that poor performance may have serious environmental consequences, or whether the potential poor performance can be assessed as having limited environmental impact if it occurs. Where the risk and consequence of a landform performing poorly is high, then the logical response is to reduce the acceptable rate of erosion used in landform design. In this case, the high risk sites are assigned rates similar to the lower rates of erosion that have been detailed previously. Similarly, if the risk and consequence of the landform performing poorly is low, then it would be reasonable for the landform design to accept a higher acceptable erosion rate. For low risk sites, the assigned rates are similar to the higher rates of erosion previously detailed. The following weightings are suggested for application to the average erosion threshold previously identified:

- Low risk sites: $50 \%$ increase in acceptable erosion rate to $9 t / h a / y$.

- Medium risk sites: acceptable erosion rates to remain at $6 \mathrm{t} / \mathrm{ha} / \mathrm{y}$.

- High risk sites: $50 \%$ reduction in acceptable erosion rate to $3 \mathrm{t} / \mathrm{ha} / \mathrm{y}$.

Where the design process can also consider peak erosion rates, it is suggested that those rates be capped to a $100 \%$ increase on the average threshold rates listed above. Assessment of risk and consequence is therefore, an important component of the planning process. The following matrix (Table 1) shows how these factors can be assessed and a risk rating developed.

Table 1 Matrix of likelihood and consequence used to determine risk ratings for waste landform design

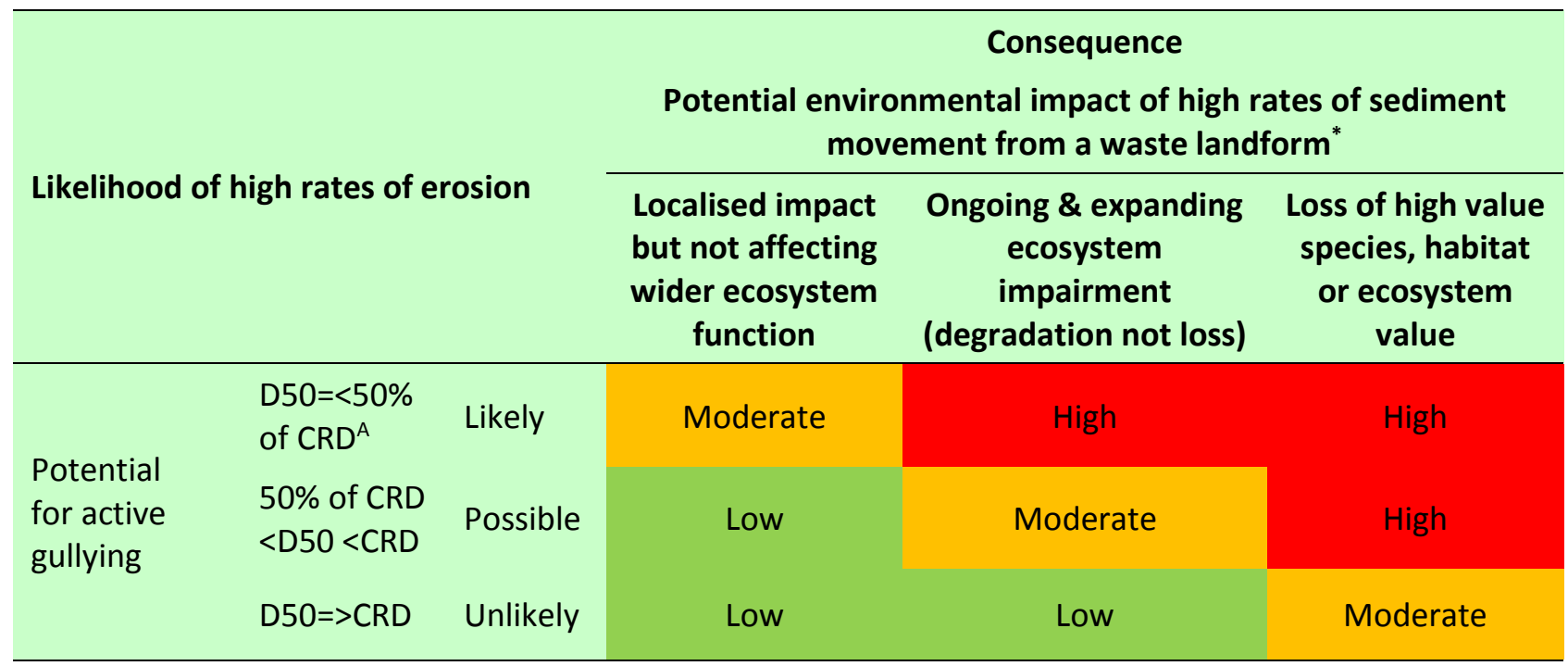

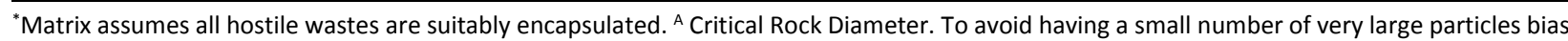
the D50 estimates, it is also stipulated that D80 should be no larger than three times D50. 


\subsection{Potential for active gullying}

This incorporates a number of inter-related site and material properties which are combined as they all affect the potential for active gullying to develop and, more importantly, to persist. Broadly, materials will vary in their resistance to gullying due to variations in the proportions of coarse particles that resist entrainment by concentrated flows. Fine grained materials will have little resistance to gully development and will not stabilise over time. In contrast, gullies are more difficult to form in materials with a significant component of coarse fragments, and have considerably greater potential to stabilise over time. To be effective, the coarse particles need to be of a diameter and density such that their critical shear for entrainment by flow is seldom, if ever, exceeded. Based on a range of erosion simulations for Pilbara sites and materials, critical rock particle diameters (CRD) (D50) have been developed for a range of batter slope options and Pilbara conditions (Table 2). To avoid having a small number of very large particles bias the D50 estimates, it is also stipulated that D80 should be less than three times D50. The likelihood of active and persistent gully development is assessed as:

- Likely: material with competent rock and having D50 $<50 \%$ of CRD.

- Possible: material with competent rock and having D50 between $50 \%$ and $99 \%$ of CRD.

- Unlikely: material with competent rock and having D50 =>CRD.

Table 2 Critical rock diameters (D50) for a range of batter heights under Pilbara conditions. Calculations considered a slope of $18^{\circ}$ gradient and assumed rock density of $2.8 \mathrm{~g} / \mathrm{cm}^{2}$

\begin{tabular}{cc}
\hline Lift height $(\mathbf{m})$ & Critical rock diameter $(\mathbf{m m})$ \\
\hline 60 & 125 \\
20 & 70 \\
10 & 55 \\
5 & 45 \\
\hline
\end{tabular}

\subsection{Encapsulated wastes}

An important consideration is whether there is encapsulated underlying material that, if exposed, would either result in a rapid and/or large increase in erosion rates (e.g. dispersive, clay rich waste) or in serious environmental consequences due to its properties (e.g. AMD, salinity, radioactivity, asbestiform minerals). So, there is a need not only to identify which properties are of concern, but also to define 'encapsulated'. For example, if the materials of concern have a $12 \mathrm{~m}$ thick cover, then the likelihood of them being exposed is low compared to a material covered by a thinner layer of material. It is proposed that 'encapsulated' considers only materials for which the depth of coverage is such that exposure is unlikely, with a depth of $>4 \mathrm{~m}$ being adopted. Where encapsulated wastes of concern are present at a depth $\leq 4 \mathrm{~m}$, then the likelihood of serious erosion occurring would be set as 'likely', and in many cases, the potential environmental impacts would also be severe, so that the assessed risk rating would commonly (though not necessarily) be 'high'.

\subsection{Assessing potential environment impacts}

Effectively, there are two considerations:

1. Sediment movement in runoff from the waste landforms.

2. The potential impact of sediment on the receiving environments.

The effectiveness of sediment movement will depend on the degree of connectivity between waste landforms and some specific receiving environment, and is likely to depend on proximity and flow paths. Where there are barriers, buffers, or blankets present in the flow path that can be expected to 
control/prevent sediment movements, then sediment movement is likely to have localised impact only. Where there is greater connectivity between the sediment source (waste landform) and the receiving environment, the likely consequences will depend on both the degree of connectivity and the sensitivity of the receiving environment. Where connectivity is somewhat restricted and/or the receiving environment is not considered to have high value or sensitivity, then there would be considered to be potential for "ongoing \& expanding ecosystem impairment (degradation not loss)" (Table 1). Alternatively, where connectivity is high and the receiving environment is considered to be of high value and/or sensitivity, then the consequences would include "loss of high value species, habitat or ecosystem value" (Table 1).

\section{Conclusion}

The review of available information related to acceptable erosion rates for the Pilbara found similar erosion rates regardless of the concept considered. Values in the order of $6 \mathrm{t} / \mathrm{ha} / \mathrm{y}$ were common, and rarely were values greater than $12 \mathrm{t} / \mathrm{ha} / \mathrm{y}$ reported. Rates that matched observed soil renewal rates (formation and dust accumulation) and those that managed the risk of gully formation were the most relevant for application to mine landforms in the Pilbara.

The guideline that was developed is based on these values, while also factoring in risks associated with exposure of encapsulated wastes and offsite environmental impacts. The acceptable erosion rates allow the suitability of landform designs to be assessed for erosion risk, as part of the many factors upon which a suitable rehabilitation design is decided.

\section{Acknowledgement}

This project was initiated by the PRG and sponsored by four PRG members: BHP, Fortescue Metals Group, Rio Tinto, and Roy Hill. The project was managed and completed by Landloch Pty Ltd with cooperation and engagement of all parties facilitated by the Western Australian Biodiversity Science Institute. The authors thank the PRG representatives of the four sponsoring companies for the provision of data, guidance, and useful comments in the drafting of this document. In particular, we gratefully acknowledge the input from Tony Webster (BHP), Kirsty Beckett and Todd Edwards (Fortescue Metals Group), Barry Jilbert and Chantal Latham (Rio Tinto), Todd Bell and John Wynne (Roy Hill), and Guy Boggs (Western Australian Biodiversity Science Institute).

\section{References}

Alexander, EB 1988, 'Rates of soil formation-implications for soil-loss tolerance', Soil Science, vol. 145, no. 1, pp. 37-45.

Berghofer, P \& Howard, E 2016 'Measuring gully activity and rehabilitation success at Nifty Copper Mine', Proceedings of the Goldfields Environmental Management Workshop, Goldfields Environmental Management Group, Kalgoorlie.

Bini, C \& Gaballo, S 2006, 'Pedogenic trends in anthrosols developed in sulfidic mine spoils: A case study in the Temperino mine archaeological area (Campiglia Marittima, Tuscany, Italy)', Quaternary International, vol. 156/157, pp. 70-78, https://doi.org/10.1016/j.quaint.2006.05.033

Blandford, DC 2010, West Pilbara Iron Ore Project. An investigation into the soils and soil landscapes of the Hardey project area (incorporating waste characterisation), D.C. Blandford \& Associates Pty Ltd, viewed 15 May 2019, http://www.epa.wa.gov.au/sites/default/files/API_documents/1943-APPENDIX\%204\%20An\%20investigation\%20into\%20 the\%20Soils\%20and\%20Soil\%20Landscapes\%20of\%20the\%20Hardey\%20Project\%20Area.pdf

Braun, T, Howard, E \& Chesal, T 2018, 'Planning closure of the Arizona Closed Sites using field erodibility studies and erosion modelling', Proceedings of the Second International Congress of Planning for Closure of Mining Operations, GECAMIN, Santiago.

Browning, GM, Parish, CL \& Glass, JA 1947, 'A method for determining the use and limitation of rotation and conservation practices in control of soil erosion in lowa', Agronomy Journal, vol. 39, no. 1, pp. 65-73, https://www.doi.org/ 10.2134/agronj1947.00021962003900010008x

Bui, EN, Hancock, GJ, Chappell, A \& Gregory, LJ 2010, Evaluation of tolerable erosion rates and time to critical topsoil loss in Australia, CSIRO Sustainable Agriculture Flagship, Canberra.

Chevron Australia Pty Ltd 2010, Draft Environmental Impact Statement/Environmental Review and Management Programme for the Proposed Wheatstone Project: Technical Appendices Q6, Q7, R1, T1, U1, V1, and W1, https://australia.chevron.com//media/australia/our-businesses/documents/wheatstone-draft-eis-ermp-technical-appendices-q6-q7-r1-s-web.pdf

Commonwealth of Australia 2016a, Mine Closure: Leading Practice Sustainable Development Program for the Mining Industry, viewed 15 May 2019, https://www.industry.gov.au/sites/default/files/2019-05/Ipsdp-mine-closure-handbook-english.pdf 
Commonwealth of Australia 2016b, Evaluating Performance: Monitoring and Auditing, Leading Practice Sustainable Development Program for the Mining Industry, viewed 15 May 2019, https://www.industry.gov.au/sites/g/files/net3906/f/July\%202018/ document/pdf/evaluating-performance-monitoring-and-auditing.pdf

Department of Mines and Petroleum 2009, Waste Rock Dumps: Environmental Notes on Mining, Government of Western Australia, viewed 15 May 2019, http://www.dmp.wa.gov.au/Documents/Environment/ENV-MEB-223.pdf

Edwards, K \& Zierholz, C 2007, 'Soil formation and erosion rates', in PEV Charman \& BW Murphy (eds), Soils: their properties and management, $3^{\text {rd }}$ Edition, Oxford University Press, South Melbourne.

Evans, KG \& Loch, RL 1996, 'Laboratory rainfall simulator studies of selected open-cut coal mine overburden spoils from Central Queensland', Soil Research, vol. 35, no. 1, pp. 15-30, https://doi.org/10.1071/\$95010.

Flanagan, DC \& Livingston, SJ 1995, WEPP user summary, NSERL Report No. 11, Agricultural Research Service, National Soil Erosion Research Laboratory, U.S. Department of Agriculture.

Gallagher, E 2008, Pilbara specific runoff coefficients, Masters thesis, University of Technology, Sydney.

Govers, G \& Poesen, J 1988, 'Assessment of the interrill and rill contributions to total soil loss from an upland field plot', Geomorphology, vol. 1, no. 4, pp. 343-354, https://doi.org/10.1016/0169-555X(88)90006-2

Hancock, GR 2004, 'The use of landscape evolution models in mining rehabilitation design', Environmental Geology, vol. 46, no. 5, pp. 1432-1495, https://doi.org/10.1007/s00254-004-1030-3

Hancock, GR, Loch, RJ \& Willgoose, GR 2003, 'The design of post-mining landscapes using geomorphic principles', Earth Surface Processes and Landforms, vol. 28, no. 10, pp. 1097-1110, https://doi.org/10.1002/esp.518

Hancock, GR, Evans, KG, Willgoose, GR, Moliere, DR, Saynor, MJ \& Loch, RJ 2000, 'Medium term erosion simulation of an abandoned mine site using the SIBERIA landscape evolution model', Australian Journal of Soil Research, vol. 38, no. 2, pp. 249-263, https://doi.org/10.1071/SR99035

Heimsath, AM, Fink, D \& Hancock, GR 2009, 'The 'humped' soil production function: eroding Arnhem Land, Australia', Earth Surface Processes and Landforms, vol 34, no. 12, pp. 1674-1684, https://doi.org/10.1002/esp.1859

Heimsath, AM, Dietrich, WE, Nishiizumi, K \& Finkel, RC 1997, 'The soil production function and landscape equilibrium', Nature, vol. 388, pp. 358-361, https://doi.org/10.1038/41056

Howard, EJ \& Lowe, SM 2014, 'Innovative rehabilitation of marine dredge spoil', Proceedings of the Ninth International Conference on Mine Closure, University of the Witwatersrand, viewed 15 May 2019, https://www.researchgate.net/ publication/281052544_Innovative_rehabilitation_marine_dredge_spoil

Howard, EJ, Loch, RJ \& Vacher, CA 2011, 'Evolution of landform design concepts', Mining Technology, vol. 120, no. 2, pp. 112-117, https://doi.org/10.1179/037178411X12942393517615

Howard, E, Shemeld, J \& Loch, R 2010, 'Ramelius Resources' Wattle Dam Project: Achieving bond reduction through leading practice', Proceedings of the Goldfields Environmental Management Workshop, Goldfields Environmental Management Group, Kalgoorlie, pp. 236-246

Kiefert, L, McTainsh, GH \& Nickling, WG 1996, 'Sedimentological characteristics of Saharan and Australian dusts' in S Guerzoni \& R Chester (eds), The impact of Desert Dust Across the Mediterranean, Kluwer Academic Publishers, Dordrecht.

Klingebiel, AA 1961, 'Soil factor and soil loss tolerance', Soil Loss Prediction-North Dakota, South Dakota, Nebraska, and Kansas, Nebraska Department of Agriculture, Lincoln.

Larson, WE \& Stewart, BA 1990, 'Thresholds for soil removal for maintaining cropland productivity', Proceedings of the Soil Quality Standards Symposium, Soil Science Society of America, San Antonio.

Loch, RJ 1997, 'Landform design - better outcomes and reduced costs by applying science to above- and below-ground issues', Proceedings of the 22nd Annual Environmental Workshop, Minerals Council of Australia, Adelaide.

Loch, RJ 2010, Final Report - Sustainable landscape design for coal mine rehabilitation, Project No. C18024, Australian Coal Association Research program.

Loch, RJ \& Donnollan, TE 1983, 'Field rainfall simulator studies on two clay soils of the Darling Downs, Queensland. I. The effects of plot length and tillage orientation on erosion processes and runoff and erosion rates', Australian Journal of Soil Research, vol. 21, no. 1, pp. 33-46, https://doi.org/10.1071/SR9830033

Loch, RJ \& Lowe, SM 2008, 'A logical framework for design, construction, and rehabilitation of minesite waste rock dumps', in AB Fourie (ed.), Proceedings of the First International Seminar on the Management of Rock Dumps, Stockpiles, and Heap Leach Pads, Australian Centre for Geomechanics, Perth, pp. 257-265.

Loch, RJ \& Willgoose, GR 2000a, 'Rehabilitated landforms: designing for stability', Proceedings of the 2000 Workshop on Environmental Management in Arid and Semi-arid Areas, Goldfields Land Rehabilitation Group, Kalgoorlie, pp. 39-44, https://www.gemg.org.au/ckfinder/userfiles/files/2000\%20GEMG\%20Proceedingss.pdf

Loch, RJ \& Willgoose, GR 2000b, 'Design of Stable Rehabilitated Landforms', Proceedings of the Third Australian Minerals and Energy Environmental Foundation Innovation Conference, Australian Minerals and Energy Environmental Foundation, Brisbane, pp. 14-20.

Loch, RJ, Vacher, CA \& Lowe, SM 2008, 'Topsoil organic carbon and nutrient considerations for waste dump rehabilitation', Proceedings of the Goldfields Environmental Management Workshop, Goldfields Environmental Management Group, Kalgoorlie, pp. 102-108.

Logan, TJ 1982, 'Improved criteria for developing soil loss tolerance levels for cropland', in DM Kral \& S Hawkins (eds), Determinants of Soil Loss Tolerance, American Society of Agronomy, Madison, ASA Special Publication Number 45, pp. 131-138.

Lu, H, Prosser, IP, Moran, CJ, Gallant, JC, Priestley, G \& Stevenson, JG 2003, 'Predicting sheetwash and rill erosion over the Australian continent', Australian Journal of Soil Research, vol. 41, no. 6, pp. 1037-1062, https://doi.org/10.1071/SR02157 
McFarlane, DJ, George, RJ, Loughran, RJ, Elliott, GL, Ryder, AT, Bennett, D \& Tille, PJ 2000, A national reconnaissance survey of soil erosion: Australia - Western Australia. A report for the Australian National Landcare Program, Department of Primary Industries and Energy, University of Newcastle, Sydney.

Meyer, LD, Foster, GR \& Romkens, MJM 1975, 'Source of soil eroded by water from upland slopes', Proceedings of the 1972 Sediment Yield Workshop, U.S. Department of Agriculture, Oxford, Mississippi, pp. 177-189.

McCormack, DE, Young, KK \& Kimberlin, LW 1982, 'Current criteria for developing soil loss tolerance', Determinants of Soil Loss Tolerance, American Society of Agronomy, Madison, ASA Special Publication Number 45, pp. 95-112.

Moliere, DR, Evans, KG, Willgoose, GR \& Saynor, MJ 2002, Temporal Trends in Erosion and Hydrology for a Post-mining Landform at Ranger Mine, Supervising Scientist Report 165, Department of the Environment and Energy, Darwin.

Musgrave, GW 1947, 'The quantitative evaluation of factors in water erosion, a first approximation', Journal of Soil and Water Conservation, vol. 2, no. 3, pp. 133-138.

Renard, KG, Foster, GR, Weesies, GA, McCool, DK \& Yoder, DC 1997, Predicting soil erosion by water: A guide to conservation planning with the revised universal soil loss equation (RUSLE), Agriculture Handbook No. 703, United States Department of Agriculture, Springfield.

Rollins MB 1981, "'T" factors on rangelands', Proceedings of the Workshop on Estimating Erosion and Sediment Yield on Rangelands, U.S. Department of Agriculture, Oakland, pp. 197-198, https://www.tucson.ars.ag.gov/unit/publications/PDFfiles/408.pdf

Sawkins, D, Verboom, WH \& Pate, JS 2011, Native vegetation in Western Australia is actively involved with soil formation, Bulletin 4823, Department of Agriculture and Food, Perth.

Smith, DD 1941, 'Interpretation of soil conservation data for field use', Agricultural Engineering, vol. 22, pp. $173-175$.

Spain, AV \& Hollingsworth, I 2016, 'Selected properties of the incipient soils developing on coal mining wastes, Bowen Basin, Australia', in AB Fourie \& M Tibbett (eds), Proceedings of the Eleventh International Conference on Mine Closure, Australian Centre for Geomechanics, Perth, pp. 173-186.

Squires, H, Priest, M, Sluiter, I \& Loch, RJ 2012, 'Leading practice waste dump rehabilitation at the Ginkgo mineral sands mine', in AB Fourie \& M Tibbett (eds), Proceedings Seventh International Conference on Mine Closure, Australian Centre for Geomechanics, Perth, pp. 59-72.

Stocking, M 1978, 'A Dilemma for Soil Conservation', Area, vol. 10, pp. 306-308.

Tille, P 2006, Soil-landscapes of Western Australia's Rangelands and Arid Interior, Resource Management Technical Report 313, Department of Agriculture and Food, Perth.

van Vreeswyk, AME, Leighton, KA, Payne, AL \& Henning, P 2004, An inventory and condition survey of the Pilbara region, Western Australia, Technical Bulletin 92, Department of Agriculture and Food, Perth.

Verboom, WH, Pate, JS, Abdelfattah, MA \& Shahid, SA 2013, 'Effects of Plants on Soil-Forming Processes', in SA Shahid, FK Taha \& MA Abdelfattah (eds), Developments in Soil Classification, Land Use Planning and Policy Implications: Innovative Thinking of Soil Inventory for Land Use Planning and Management of Land Resources, Springer Science+Business Media Dordrecht, London, pp. 329-344.

Verheijen, FGA, Jones, RJA, Rickson, RJ \& Smith CJ 2009, 'Tolerable versus actual soil erosion rates in Europe', Earth-Science Reviews, vol. 94, pp. 23-38.

Wight, JR \& Siddoway, FH 1982, 'Determinants of soil loss tolerance for rangelands', Determinants of Soil Loss Tolerance, Publication 45, American Society of Agronomy, Madison, pp. 67-74.

Willgoose, GR \& Hancock, GR 2011, 'Applications of long-term erosion and landscape evolution models', in RPC Morgan \& MA Nearing (eds), Handbook of Erosion Modelling, Wiley Blackwell, Chichester.

Willgoose, GR \& Riley, SJ 1998, 'The long-term stability of engineered landforms of the Ranger Uranium Mine, Northern Territory, Australia: Application of a catchment evolution model', Earth Surface Processes and Landforms, vol. 23, no. 3, pp. 237-259, https://doi.org/10.1002/(SICI)1096-9837(199803)23:3<237::AID-ESP846>3.0.CO;2-X

Wischmeier, WH \& Smith, DD 1965, Predicting rainfall-erosion losses from cropland east of the Rocky Mountains, Agriculture Handbook No. 282, U.S. Department of Agriculture, Washington.

Zingg, AW 1940, 'Degree and length of land slope as it affects soil loss in runoff', Agricultural Engineering, vol. 21, pp.59-64. 
